\title{
Potential of invasive alien species Clidemia hirta as antibacterial against Salmonella typhi and Staphylococcus aureus
}

\author{
MENTARI PUTRI PRATAMI ${ }^{1}$, MIFTAHUL HUDA FENDIYANTO ${ }^{1,2, \vartheta}$, RIZKY DWI SATRIO ${ }^{1,2}$, \\ I DEWA KETUT KERTA WIDANA ${ }^{3}$, ISNA AROFATUN NIKMAH ${ }^{1}$, NASTITI INTAN PERMATA SARI ${ }^{1}$, \\ MO AWWANAH ${ }^{1}$, NADYA FARAH ${ }^{1}$, DIDI DARMADI ${ }^{4}$ \\ ${ }^{1}$ Department of Biology, Universitas Pertahanan. Kampus Universitas Pertahanan, Kawasan IPSC, Sentul, Bogor 16810, West Java, Indonesia. \\ "email: miftahul.fendiyanto@idu.ac.id \\ ${ }^{2}$ Laboratory of Plant Physiology and Molecular Biology, Department of Biology, Faculty of Mathematics and Natural Sciences, Institut Pertanian Bogor. \\ Jl. Agatis, Kampus IPB Darmaga, Bogor 16680, West Java, Indonesia. \\ ${ }^{3}$ Disaster Management Program, Universitas Pertahanan, Kawasan IPSC, Sentul, Bogor 16810, West Java, Indonesia \\ ${ }^{4}$ Indonesian Agency for Agricultural Research and Development. Jl. Pang Nyak Makam No. 27, Banda Aceh 24415, Aceh, Indonesia
}

Manuscript received: 19 April 2021. Revision accepted: 25 May 2021.

\begin{abstract}
Pratami MP, Fendiyanto MH, Satrio RD, Widana IDKK, Nikmah IA, Sari NIP, Awwanah M, Farah N, Darmadi D. 2021. Potential of invasive alien species Clidemia hirta as antibacterial against Salmonella typhi and Staphylococcus aureus. Biodiversitas 22: 3363-3369. Clidemia hirta D. Don is an invasive alien species (IAS) that is a threat to biodiversity in tropical country particularly Indonesia, and remains underutilized to date. Conversely, prevalence of typhus in Indonesia is generally higher every year. Thus, the aim of this study was to detect phytochemicals in ethanolic and aqueous extracts of $C$. hirta and their antibacterial activity against Salmonella typhi and Staphylococcus aureus. The research methods included sample identification, generating the simplicia, determination of water content, extraction, phytochemical screening tests, and antibacterial activity tests. Identification was made based on morphological characteristics. The water content in the dried powder of simplicia was $12.26 \pm 0.39 \%$. Phytochemical results showed that $70 \%$ ethanol extract of $C$. hirta contained flavonoids, saponins, tannins, and triterpenoids compounds. In addition, aqueous extract of $C$. hirta showed positive results on flavonoids, saponins, tannins, and steroids tests. Antibacterial activity results showed that ethanolic extracts of $C$. hirta inhibited $S$. typhi and S. aureus at all concentrations, while aqueous extract inhibited bacterial growth in only $12.5 \%$ and $25 \%$ concentrations. These findings indicate that $C$. hirta has antibacterial activity that inhibits S. typhi and S. aureus. This information can be used for adding preliminary data to metabolite interest researchers, i.e., biologists and biotechnologists in the future.
\end{abstract}

Keywords: Clidemia hirta, phytochemicals, Salmonella typhi, Staphylococcus aureus

\section{INTRODUCTION}

Indonesia is a country with high biodiversity and sources of germplasm. This biodiversity is supported by fertile soils and abundant natural resources. Today, biodiversity and sources of germplasm in Indonesia are threatened because local plants are invaded by invasive foreign plants. Invasive alien species (IAS) have invaded many National Parks, Tourist Attractions, agricultural land, and vegetation in Indonesia. The agricultural land area of Indonesia is 8.59 million hectares of the total land area of 192 million hectares (Fendiyanto et al. 2019a; Miftahudin et al. 2021). The agricultural land is gradually unable to meet the needs of local food supplies, one of disturbance is caused by an invasive plant that attacks rice (Hossain 2009). Weeds can cause economic and environmental disruption (Alpert et al. 2000). Invasive plants are plants that are not native to a community and dominate a certain area. Weeds can reduce the composition of native vegetation so that they can threaten biodiversity in an area. Several tourist parks, nature reserves and national parks in Indonesia have been attacked by weeds.
National Parks, Tourist Parks, and Nature Reserves in Indonesia have been invaded by weed species. The classification of invasive plants is based on Tjitrosoedirdjo (2005). The number of plants classified as invasive alien species (IAS) belongs to 187 families and 1936 species. Four invasive plants that grow in Telaga Warna Nature Park are Eupatorium sordidum, Eupatorium inulifolium, Clidemia hirta, and Ageratum conyzoides (Badan 2010). Clidemia hirta D. Don is a weed plant that has not been fully utilized. $C$. hirta extraction results showed antibacterial potential (Abrahim 2010). The antimicrobial compounds contained in the leaves of $C$. hirta have the potential for further study in the manufacture of antibiotics. Until now, most of the products on the biotechnology market for antibiotic compounds are still obtained from bacteria, actinomycetes, and fungi (Sumardi 1998). Therefore, there is an opportunity to use the C. hirta plant as an antibiotic.

Invasive alien species (non-native) are generally introduced by humans, which threaten ecosystems, habitats, or other species and cause global changes in the environment (Pejchar and Mooney 2009). C. hirta is an invasive plant that disturbs agricultural land and plantations 
in Indonesia. On the other hand, there is still a high prevalence of typhus caused by bacteria in Indonesia, with $37 \%$ of people suffering from high fever symptoms in the 1990s (Azad 1990). The C. hirta plant extract showed antibacterial activity in preliminary tests to control typhus and could be further used as an antibiotic. Thus, due to the presence of antibiotic compounds in C. hirta, it can be used as an antibacterial to prevent Salmonella typhi. Therefore, this research was conducted to test the antibacterial activity of C. hirta extract against S. typhi and Staphylococcus aureus.

\section{MATERIALS AND METHODS}

\section{Plant identification}

Plant samples taken from several locations around the Dramaga IPB campus, Bogor, Indonesia were identified morphologically. The morphological characters of the samples were compared to Soerjani et al. (1987) and Steenis (2006).

\section{Sample preparation and simplicia preparation}

Sample preparation includes the process of sorting, drying, and milling of the leaves into powder form (Kemenkes 1995; Winarno 1997). The sorting process begins with picking the leaves and separating them from other parts. The leaves were cleaned, then washed and dried at room temperature. After that, leaves were dried in an oven at $45^{\circ} \mathrm{C}$ for 2 weeks. The dried leaves of $C$. hirta were then crushed using a blender and kept it in a jam bottle for further analysis.

\section{Determination of water content}

A total of 2 grams of the dried sample was placed into a cup, then kept in an oven at $105^{\circ} \mathrm{C}$ for 30 mins. The dried leaves were taken out and cooled in a desiccator for 15 mins and then weighed. Water content was determined thrice by the following method of Fendiyanto and Satrio (2020). The water content was calculated by the following formula:

Water Content $=((\mathrm{x}-\mathrm{y})) / \mathrm{a} \times 100 \%$

Where:

$\mathrm{x}=$ plate and sample weight before drying $(\mathrm{g})$

$\mathrm{y}=$ plate and sample weight after drying $(\mathrm{g})$

$\mathrm{a}=$ initial sample weight $(\mathrm{g})$

\section{Leaf extraction of $C$. hirta}

The leaves of C. hirta were extracted using $70 \%$ ethanol and distilled water. Extraction was done using $70 \%$ ethanol solvent based on Harbone (1987) method while extraction using $\mathrm{ddH}_{2} \mathrm{O}$ solvent was carried out using the same method, but with some modifications. In ethanol extraction, a 10 grams sample was mixed with $100 \mathrm{~mL}$ of $70 \%$ ethanol and covered with aluminum foil. Maceration was done for $2 \times 24 \mathrm{~h}$, with filtering every $24 \mathrm{~h}$. Extraction in distilled water was done in a 1:10 ratio by boiling method. The $C$. hirta leaves were boiled for $2 \mathrm{~h}$. The boiling water was allowed to stand, then filtered and the filtrate was collected. The filtrate was then evaporated and concentrated using rotary evaporator to obtain a powdered extract (Harvey 2000).

\section{Phytochemical screening}

The phytochemical analysis was conducted to determine the existence of active compounds contained in C. hirta extract. Qualitative screening of flavonoids, saponins, tannins, quinine, coumarin, steroids, triterpenoids, and alkaloids was performed by Harbone (1987). Flavonoids, saponins, tannins, and quinones were estimated by the method of Harbone (1987). $0.5 \mathrm{~g}$ of active fraction was dissolved in $10 \mathrm{~mL}$ of water and heated over a water bath, and then solution was divided into four tubes. In the first tube, approximately $100 \mathrm{mg}$ of magnesium powder was added and then $1 \mathrm{~mL}$ of concentrated hydrochloric acid and $3 \mathrm{~mL}$ of amyl alcohol were added, shaken vigorously, and allowed to separate. If red, yellow, orange color was appeared on the amyl alcohol layer it indicates the presence of flavonoids. The second tube was shaken vertically for 10 seconds, a stable foam was formed, left for 10 minutes, and added 1 drop of $1 \%$ hydrochloric acid, if the foam does not disappear, it indicates the presence of saponins. In the third tube, added a few drops of $1 \mathrm{~N}$ sodium hydroxide, the presence of a red solution indicates the presence of quinones. In the fourth tube, added a few drops of $1 \%$ iron (III) chloride solution, the formation of a dark blue or blackish green solution indicates the presence of tannins.

For coumarin test, a total of 0.5 grams of the active fraction was mixed with $10 \mathrm{~mL}$ of ether, after being cold then filtered. The filtrate was evaporated, $10 \mathrm{~mL}$ of hot water was added and cooled then $0.5 \mathrm{~mL}$ of $10 \%$ ammonia solution was added. The presence of green or blue fluorescence in UV light indicates the presence of coumarin.

For the steroid/triterpenoid test, a total of $20 \mathrm{mg}$ of extract was added with $20 \mathrm{~mL}$ of ether and macerated for 2 hours, then filtered. The filtrate was then evaporated in an evaporator cup until a residue was obtained. The residue was then added with Liebermann Bouchard's reagent (2 drops of anhydrous acetic acid and 1 drop of concentrated sulfuric acid). The formation of red color indicates positive for triterpenoid, while the green color results positive for steroids.

For the alkaloids test, a total of $0.5 \mathrm{~g}$ of the extract was moistened with ammonia and added with chloroform. The filtrate in the form of an organic solution was then transferred to a new test tube and $10 \%$ hydrochloric acid was added. The acid layer was then removed in a new test tube and a few drops of Dragendorff reagent were dropped, if a brick-red precipitate was formed it indicates the presence of alkaloids.

\section{Antibacterial activity test}

The antibacterial test was conducted to determine the potential of each extract fraction. Antibacterial tests were conducted using the disc method (Magaldi et al. 2004; Valgas et al. 2007) and the cross streak method (Lertcanawanichakul and Sawangnop 2008). S. typhi and S. aureus bacterial suspensions were mixed in nutrient broth 
(NB) liquid media. $2 \mathrm{~mL}$ of each bacterial suspension was mixed into the nutrient broth agar and then poured into Petri plates. Discs $(2 \mathrm{~mm})$ immersed in $C$. hirta extracts were placed on Petri plates and incubated at $37^{\circ} \mathrm{C}$ for 24 hours. Microbial activity was tested by the appearance of an inhibition zone around the disc. For the cross streak method, about $2 \mathrm{~mL}$ of extract was mixed with LA medium [3 $\mathrm{g}$ of beef extract (Merck, USA), $5 \mathrm{~g}$ of peptone (Merck, USA), $15 \mathrm{~g}$ of agar (Merck, USA), and $1 \mathrm{~L}$ of distilled water] Each bacterium was inoculated using the cross streak method and incubated at $37{ }^{\circ} \mathrm{C}$ for $24 \mathrm{~h}$. The presence of a clear zone or no growth of bacteria was an indicator of antibacterial activity. In addition, 5\% amoxicillin antibiotic was used as a positive control and distilled water as a negative control in this study.

\section{RESULTS AND DISCUSSION}

\section{Plant identification}

The distribution of $C$. hirta plants in the Dramaga campus of IPB, Bogor, Indonesia was relatively high. Observation results showed that $C$. hirta plants have bushy stature. The flowers were characterized by limited inflorescence, white petals, ten stamens, bisexual flowers, $0.5 \mathrm{~cm}$ long bell-shaped widened petals, and 3-4 $\mathrm{cm}$ flower stalks (Figure 1a). The leaves of $C$. hirta were characterized by 3-9 curved leaves, oval leaf shape, tapered leaf tip, heart-shaped leaf base, crenate leaf edge, hair adaxial and abaxial leaf surface, $5-18 \mathrm{~cm}$ long, wide leaves $3-10 \mathrm{~cm}$ long, leaves without stipules, and sparse hairy petiole (Figure 1b). The stems of $C$. hirta were erect, covered with fine hairs, facing opposite sides, $82-190 \mathrm{~cm}$ high (Figure 1c). The identity of $C$. hirta was found to be similar to that described in Soerjani et al. (1987) and Steenis (2006). Thus, C. hirta was classified based on observations and literature into: division: Magnoliophyta, class Magnoliopsida, order: Myrtales, family: Melastomaceae, genus: Clidemia, and species: hirta.

\section{Determination of water content}

Water content of the simplicia made from the dried leaves of $C$. hirta was determined by weighing the samples before and after drying, and the percentage was calculated based on formula described in the method section. The average value of the percent water content in the dried powder was $12.26 \pm 0.39 \%$ (Table 1 ).

\section{Extraction}

The extraction of $C$. hirta leaves was carried out in two different solvents of distilled water and $70 \%$ ethanol, which yielded two different crude extracts. Extracts were further concentrated in the Laboratory of the Center for Biological Resources and Biotechnology Research, IPB, giving two distinct powders. Qualitative analysis of the two powders exhibited that $C$. hirta extracted with distilled water gave a finer texture than using $70 \%$ ethanol solvent. Both powders were brown, but the one from $70 \%$ ethanol was darker (Figure 2).

\section{Phytochemical screening analysis}

Phytochemical analysis revealed that $70 \%$ ethanol extract of $C$. hirta showed positive tests for flavonoids, saponins, tannins, and triterpenoids. Whereas, aqueous extract of $C$. hirta showed positive results for flavonoids, saponins, tannins, and steroids (Table 2). Both the extracts exhibited negative tests for quinone, alkaloids, and coumarin.

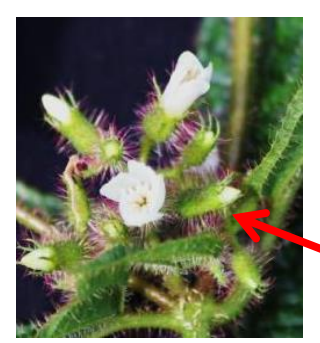

A

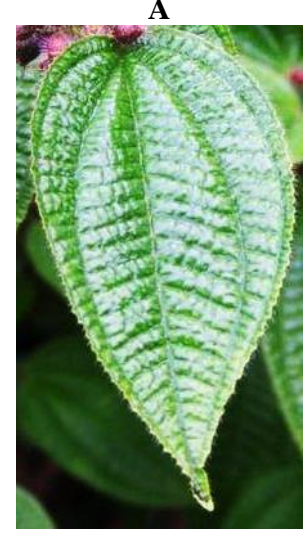

B

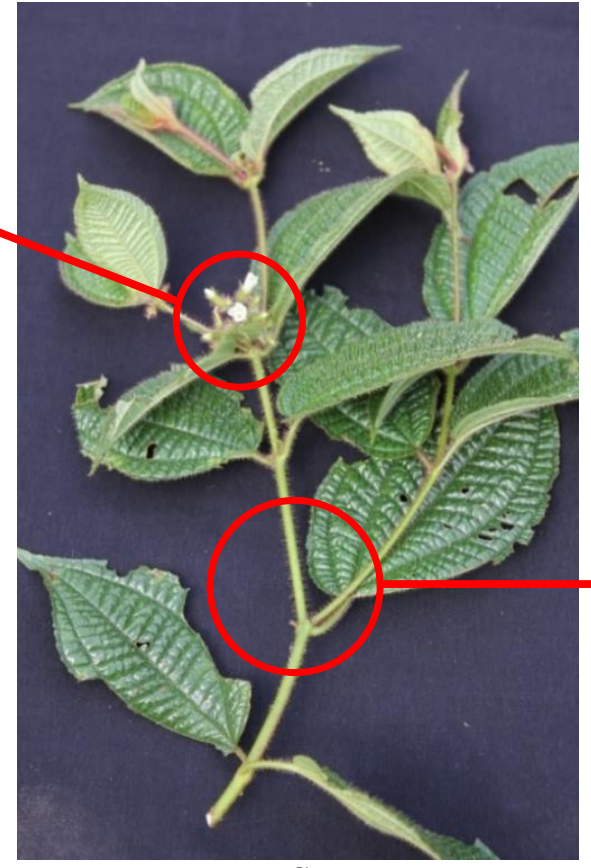

C

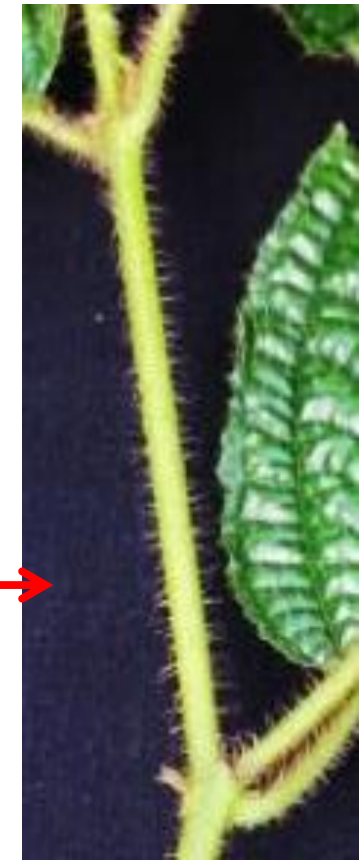

D

Figure 1. Clidemia hirta D. Don: A. Flowers, B. Leaves, and C. Stems 


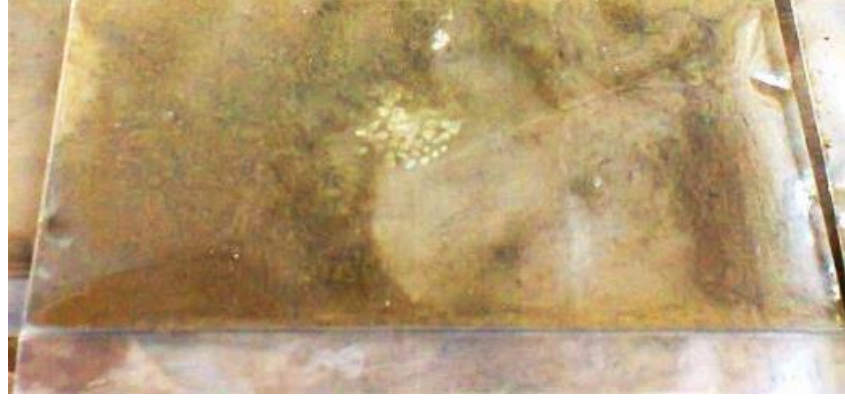

$\mathbf{A}$

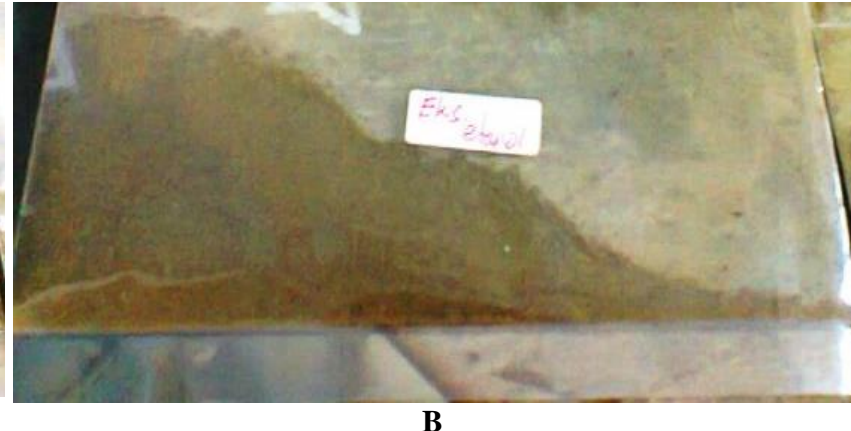

Figure 2. Leaf extract of Clidemia hirta in powder form: A. In distilled water, B. In $70 \%$ ethanol solvent

\section{Antibacterial activity}

Antibacterial activity was tested using the disc method and qualitative inhibition test. The results of the disc method did not show any significantly antibacterial activity among concentration of extracts, all extract concentrations have inhibition zone but the zone was similar. However, the cross streak-qualitative inhibition method showed difference among ethanol and aqueous extracts of $C$. hirta (Figure 3). The bactericidal properties of $C$. hirta extracts can suppress the growth of Salmonella typhi and S. aureus bacteria

Antibacterial test results showed that $C$. hirta extract was found effective in inhibiting the activity of $S$. typhi and $S$. aureus. Ethanol extract of $C$. hirta inhibited the activity of both $S$. typhi and $S$. aureus at all concentrations, whereas aqueous extracts inhibited the growth of both bacteria at only $12.5 \%$ and $25 \%$ concentrations (Table 3 ). Thus, $C$. hirta extracts have a broad spectrum of antibacterial activity.

\section{Discussion}

Invasive species are species that arise as a result of human activities, which can threaten the environment, agriculture, and other resources (Hossain 2009). Alpert et al. (2000) stated that invasive species are species that are not local species in an ecosystem, it causes disruption to the economy and environment, and negatively impacts on human health. Invasive species as species of flora or fauna, including microorganisms that live outside their natural habitat, growing rapidly because they do not have natural enemies, so they act as weeds, pests, and diseases in native species (Purwono et al. 2002).

Clidemia hirta plant is an invasive alien species that influence the Dramaga IPB campus. This is indicated by the INP (Importance Value Index) value of $17.26 \%$ of all vegetation communities in the area (Prinando 2011). Therefore, this plant is easy to find in the Dramaga IPB campus area. C. hirta is also ranked as one of the hundred most invasive alien species in the world (Lowe et al. 2000). In the present study, the invasive alien species (IAS) $C$. hirta was identified based on morphological studies including flower and leaf structures. However, the potency of $C$. hirta extract nowadays is necessary to test the antibacterial, antibiotic, antifungal activity among several microorganisms (Schunack 1990; Bauer et al. 1996; Andria 2000; Prayitno 2007), i.e., between plant extract-virus interaction (Fendiyanto et al. 2021) and spoilage fungi $-A$. niger bioactivity (Fendiyanto and Satrio 2020), and fungal metabolites (Tabasso 2006).

Table 2. Phytochemical screening of ethanolic and aqueous extracts of Clidemia hirta

\begin{tabular}{|c|c|c|}
\hline \multirow{2}{*}{ Phytochemical test } & \multicolumn{2}{|c|}{ Extracts } \\
\hline & $70 \%$ Ethanol & Aqueous \\
\hline Flavonoids & + & + \\
\hline Saponins & + & + \\
\hline Tannins & + & + \\
\hline Quinone & - & - \\
\hline Alkaloids & - & - \\
\hline Steroids & - & + \\
\hline Triterpenoids & + & - \\
\hline Coumarin & - & - \\
\hline
\end{tabular}

Table 3. Antibacterial activity of ethanolic and aqueous extracts of Clidemia hirta against Salmonella typhi and Staphylococcus aureus

\begin{tabular}{llc}
\hline \multirow{2}{*}{ Treatments } & \multicolumn{2}{c}{ Bacteria } \\
\cline { 2 - 3 } & Salmonella typhi & Staphylococcus aureus \\
\hline
\end{tabular}

Control 1

Control 2

Ethanol $0.7825 \%$

Ethanol $1.5625 \%$

Ethanol $3.125 \%$

Ethanol $6.25 \%$

Ethanol $12.5 \%$

Ethanol 25\%

$\mathrm{ddH}_{2} \mathrm{O} 0.7825 \%$

$\mathrm{ddH}_{2} \mathrm{O} 1.5625 \%$

$\mathrm{ddH}_{2} \mathrm{O} 3.125 \%$

$\mathrm{ddH}_{2} \mathrm{O} 6.25 \%$

$\mathrm{ddH}_{2} \mathrm{O} 12.5 \%$

$\mathrm{ddH}_{2} \mathrm{O} 25 \%$

\begin{tabular}{|c|c|}
\hline - & - \\
\hline- & - \\
\hline+ & + \\
\hline+ & + \\
\hline+ & + \\
\hline+ & + \\
\hline+ & + \\
\hline+ & + \\
\hline- & - \\
\hline- & - \\
\hline - & - \\
\hline- & - \\
\hline+ & + \\
\hline+ & + \\
\hline
\end{tabular}



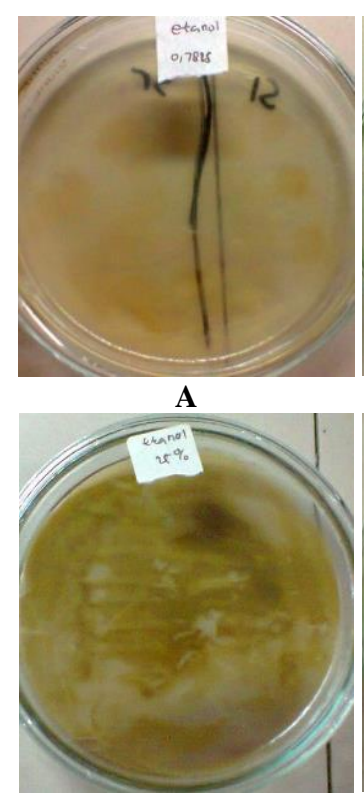

F

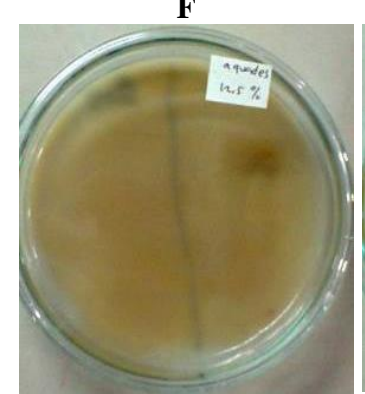

K

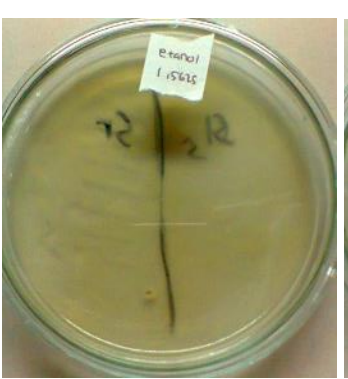

$\mathbf{B}$

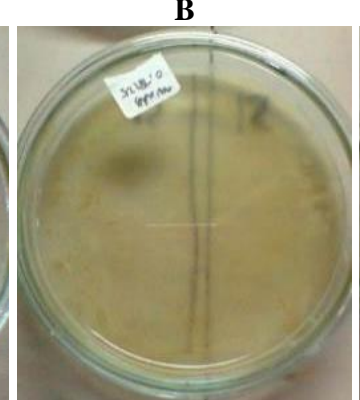

G

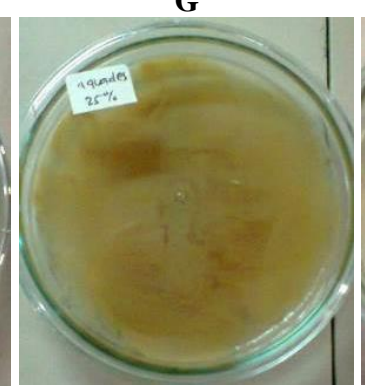

$\mathbf{L}$

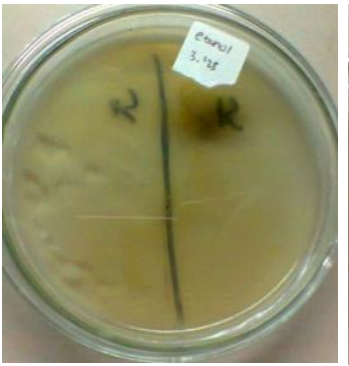

C

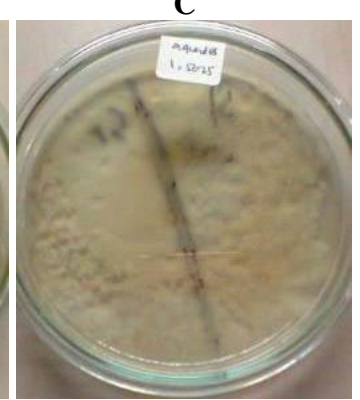

H

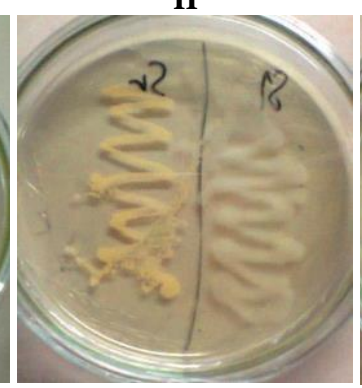

M

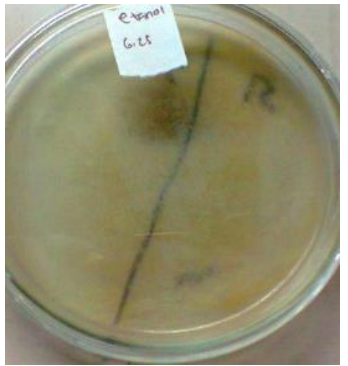

D

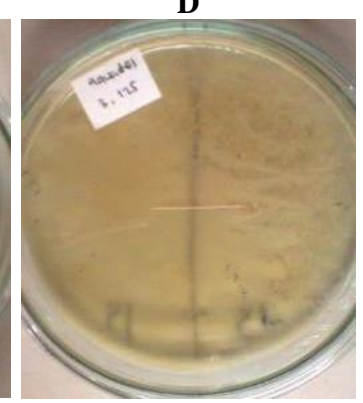

$\mathbf{I}$

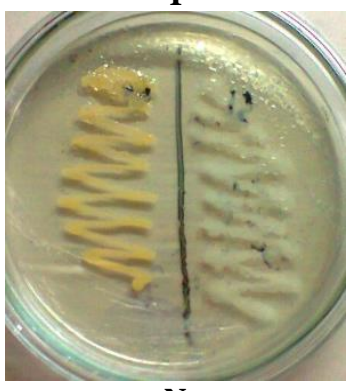

N
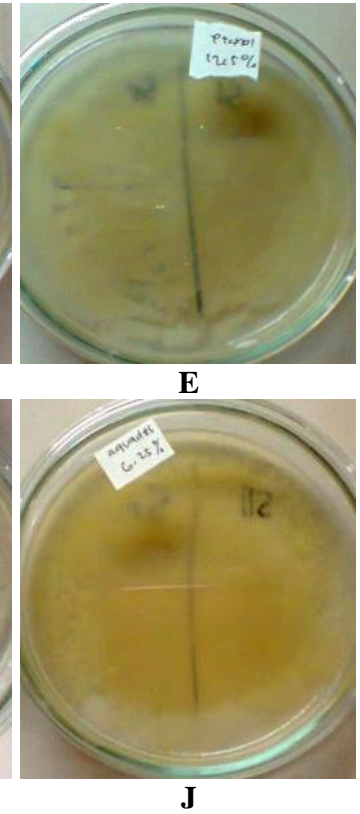

Figure 3. Antibacterial activity of Clidemia hirta extract in various concentration: Salmonella typhi (right) and Staphylococcus aureus (left). C. hirta extract (70\% ethanol solvent) using concentration of $0.7825 \%$ (A), $1.5625 \%$ (B), 3.125\% (C), 6.25\% (D), $12.5 \%$ (E), and $25 \%$ (F); Salmonella typhi (top) and S. aureus (bottom), extract of C. hirta (aqueous solvent) concentration $0.7825 \%(\mathrm{G}), 1.5625 \%(\mathrm{H})$, $3.125 \%(\mathrm{I}), 6.25 \%(\mathrm{~J}), 12.5 \%(\mathrm{~K})$, and $25 \%(\mathrm{~L})$; S. typhi (right) and S. aureus (left) in control 1, $\mathrm{ddH}_{2} \mathrm{O}(\mathrm{M})$ and control 2, without the extract $(\mathrm{N})$

Plants from the Melastomataceae family have been studied extensively for their antibacterial activity. Most of these studies confirm that this family has growth-inhibiting properties for bacteria (Gray 1995). In this study, aqueous and $70 \%$ ethanolic leaf extracts of C. hirta showed antibacterial activity against $S$. typhi and $S$. aureus, respectively. $C$. hirta has been shown to induce antibacterial activity against $S$. aureus (Melendez and Capriles 2006). Leaf extract of $C$. hirta has been reported to have bactericidal activity on Pseudomonas aeruginosa and bacteriostatic on Enterococci faecalis (Abrahim 2010). Antibacterial compounds are compounds that can interfere in bacterial growth or metabolism (Pelezar and Chan 1988). The selective nature of antibacterial substances means that the compound is harmful to a bacterium but not harmful to its host. An antibacterial compound has the minimum levels to inhibit bacteria or kill them, which are called Minimum Growth Inhibition Content (MIC) and Minimum Killing Concentration (MBC), respectively (Schunack et al. 1990). An antibacterial can have a broad spectrum if it can kill Gram-negative and Gram-positive bacteria, a narrow spectrum if it only kills Gram-positive or
Gram-negative, and a limited spectrum if it is effective against one particular bacterial species (Dwijoseputro 1990). Antibacterial compounds act in various ways to damage microbes, such as damage to cell walls, damage to the plasma membrane resulting in inhibition of cell growth or cell death, denaturing proteins and nucleic acids, inhibiting enzymes, inhibiting the synthesis of nucleic acids and proteins (Pelezar and Chan 1988).

Phytochemical test data can be used as an initial reference for antibacterial testing. Several active ingredients are known to have specificity as antibacterial agents. Alkaloids have antibacterial properties because they have the ability to intercalate DNA. The phenolic compounds contained in the sample based on the phytochemical test were tannins. Phenolic and tannin compounds have antimicrobial properties due to their ability to inactivate enzyme proteins and transport protein layers (Pelezar and Chan 1988; Scalbert 1991; PuupponenPimiä et al. 2001; Xu et al. 2015). Saponin compounds form soap foam in water and are surface-active agents. Saponins can interfere with the permeability of bacterial cell membranes (Murphy 1999). 
Phytochemical analysis revealed that $C$. hirta contains flavonoid, saponin, triterpenoid, and steroid compounds that showed antibacterial activity. Some secondary metabolites can influence the species growth and development, i.e., in the plant, arillus formation particularly in $S$. sumatrana is influenced by pyruvate and sulfur metabolism (Fendiyanto et al. 2020; Fendiyanto et al. 2021). Moreover, genes also influence the metabolism of some organisms, i.e., SnpB11 and OsGERLP influence the metabolism during species to avoid aluminum stress (Fendiyanto et al. 2019a; Fendiyanto et al. 2019b; Miftahudin et al. 2021). The secondary metabolites in $C$. hirta can investigate narrowly down to understand the mechanism of the interaction between their extract and growth of microbes, especially using biological markers. Biological marker in some species can be divided into several markers, i.e., morphological (Pratami et al. 2019), genetic (Satrio et al. 2019; Pratami et al. 2020; Miftahudin et al. 2021), physiological (Andriyanto and Fendiyanto 2019; Miftahudin et al. 2021), and metabolite markers (Fendiyanto et al. 2020; Fendiyanto et al. 2021).

The $70 \%$ ethanolic extract of C. hirta contains flavonoids, saponins, tannins, and triterpenoid compounds, while aqueous extract contains flavonoids, saponins, tannins, and steroids. Results revealed that ethanolic extracts of C. hirta inhibited S. typhi and S. aureus at all concentrations, whereas aqueous extracts inhibited bacterial growth at only $12.5 \%$ and $25 \%$ concentrations. So, this is a preliminary study of the effects of metabolites found in $C$. hirta extracts on the growth of typhoid-causing bacteria. To overcome typhus, further research is needed on the effect of extracts in vivo using a metabolic approach.

\section{ACKNOWLEDGEMENTS}

This research was partially funded by financial support from the Ministry of Research, Technology, and Higher Education P.I. MHF and RDS year 2014-2015 through PKM research. The authors acknowledged Rena Ukhraenah, Anita Aprilia, and Apip Nurdin, for their help during collection of data in the laboratory.

\section{REFERENCES}

Abrahim NB. 2010. Study on antibacterial properties of Clidemia hirta. Universiti Teknologi Mara Publishing, Malaysia.

Andria Y. 2000. Antimicrobial activity of extracts and fractions of daun sendok (Plantago major L.). Institut Pertanian Bogor, Bogor. [Indonesian]

Andriyanto M, Fendiyanto MH. 2019. Osmolyte and alkaline compound stimulation and tapping response of rubber plant (Hevea brasiliensis). J Agro Estate 3 (2): 110-120. DOI: 10.47199/jae.v3i2.101

Alpert P, Bone E, Holzapel C. 2000. Invasiveness, invasibility and the role of environmental stress in the spread of non-native plants. Perspektive Plant Ecol Evol Syst 3 (1): 52-66. DOI: 10.1078/14338319-00004.

Azad AF. 1990. Epidemiology of murine typhus. Ann Rev Entomol 35 553-569. DOI: 10.1146/annurev.en.35.010190.003005.

Bauer AW, Sherris JC, Truck M, Kirby M. 1966. Antibiotic susceptibility testing by standard single disc method. Am J Clin Path 115: 493-496. DOI: $10.1093 /$ ajcp/45.4_ts.493.
Badan LK. 2010. Baseline Information on Invasive Alien Species in Indonesia, Pilot Site Selection and Capacity Building. Badan Litbang Kehutanan, Bogor. [Indonesian]

Kemenkes KKRI. 1995. Kualitas Ekstrak Simplisia, Materia Medika Indonesia. Direktorat Jenderal Pengawasan Obat dan Makanan, Jakarta. [Indonesian]

Dwijoseputro. 1990. Basic Microbiology. Djambatan, Jakarta. [Indonesian]

Fendiyanto MH, Satrio RD, Suharsono, Tjahjoleksono A, Miftahudin. 2019a. Correlation among Snpb11 markers, root growth, and physiological characters of upland rice under aluminum stress. Biodiversitas 20 (5): 1243-1254. DOI; 10.13057/biodiv/d200514.

Fendiyanto MH, Satrio RD, Suharsono, Tjahjoleksono A, Hanarida I, Miftahudin. 2019b. QTL for aluminum tolerance on rice chromosome 3 based on root length characters. SABRAO J Breed Genet 51 (4): 451-469.

Fendiyanto MH, Satrio RD, Darmadi D. 2020. Metabolic profiling and pathway analysis in red arillus of Salacca sumatrana demonstrate significant pyruvate, sulfur, and fatty acid metabolisms. Biodiversitas 21 (9): 4361-4368. DOI: 10.13057/biodiv/d210955.

Fendiyanto MH, Satrio RD. 2020. Identification, aflatoxin content, and antagonistic test of spoilage fungi in bread to Aspergillus niger. Bioteknologi 17 (2): 60-66. DOI: 10.13057/biotek/c170202.

Fendiyanto MH, Satrio RD, Widana IDKK, Pratami MP, Nikmah IA, Darmadi D. 2021. Differential hierarchical metabolites expression of red/white Salacca sumatrana arillus and its molecular docking $\begin{array}{lllll}\text { studies. } & \text { Biodiversitas } 22 & \text { (2): 1014-1024. DOI: }\end{array}$ 10.13057/biodiv/d220258

Gray W. 1995. Diagnostic Cytopathology. Churchill Livingstone, Edinburgh, UK.

Harbone HB. 1987. Phytochemical Methods. Institut Teknologi Bandung Press, Bandung. [Indonesian]

Harvey D. 2000. Modern Analytical Chemistry. McGraw Hill Book, New York.

Hossain MK. 2009. Alien Invasive Plant Species and Their Effect on Hill Forest Ecosystem of Bangladesh, Invasive Plants and Forest Ecosystem. CRC Press, New York. DOI: 10.1201/9781420043389.sec2

Lertcanawanichakul M, Sawangnop S. 2008. A comparison of two methods used for measuring the antagonistic activity of Bacillus species. Walailak J Sci Tech 5: 161-171. DOI: 10.2004/wjst.v5i2.86.

Lowe S, Browne M, Boudjelas S, De Poorter M. 2000. 100 of The World's Worst Invasive Alien Species: A Selection from The Global Invasive Species Database. Invasive Species Specialist Group (ISSG), Auckland.

Magaldi S, Mata-Essayag S, Hartung de Capriles C. 2004. Well diffusion for antifungal susceptibility testing. Intl J Infect Dis 8: 39-45. DOI: 10.1016/j.ijid.2003.03.002.

Miftahudin M, Roslim DI, Fendiyanto MH, Satrio RD, Zulkifli A, Umaiyah EI, Chikmawati T, Sulistyaningsih YC, Suharsono S, Hartana A, Nguyen HT, Gustafson JP. 2021. OsGERLP: A novel aluminum tolerance rice gene isolated from a local cultivar in Indonesia. Plant Physiol Biochem 162: 86-99. DOI: 10.1016/j.plaphy.2021.02.019.

Melendez PA, VA Capriles. 2006. Antibacterial properties of tropical plants Puerto Rico. Phytomedicine 13 (4): 272-276. DOI: 10.1016/j.phymed.2004.11.009.

Murphy MC. 1999. Plant products as antimicrobial agents. Clin Microbiol Rev 12: 564-582. DOI: 10.1128/CMR.12.4.564

Pejchar L, Mooney HA. 2009. Invasives Species, Ecosystem Service and Human Well-being. Trends Ecol Evol 24 (9): 497-504. DOI: 10.1016/j.tree.2009.03.016.

Pelezar MJ, Chan ESC. 1988. Principle of Microbiology. Universitas Indonesia Press, Jakarta. [Indonesian]

Pratami MP, Chikmawati T, Rugayah R. 2019. Short Communication: Further morphological evidence for separating Mukia Arn. from Cucumis L. Biodiversitas 20 (01): 211-217. DOI: 10.13057/biodiv/d200124.

Pratami MP, Chikmawati T, Rugayah R. 2020. Genetic diversity of Cucumis and Mukia (Cucurbitaceae) based on ISSR markers. SABRAO J Breed Genet 52 (2): 127-143.

Prayitno T. 2007. Extraction, Fractionation, and Test of Bioactive Compounds from Leaves Clinacanthus muthans Lincau. Institut Pertanian Bogor Press, Bogor. [Indonesian] 
Prinando M. 2011. Diversity of Invasive Alien Plant Species at IPB Dramaga Campus, Bogor. Institut Pertanian Bogor Press, Bogor [Indonesian]

Purwono B, Wardhana BS, Wijanarko K, Setyowati E, Kurniawati DS 2002. Keanekaragaman Hayati dan Pengendalian Jenis Asing Invasif. Menteri Lingkungan Hidup Republik Indonesia dan The Nature Consevancy, Jakarta. [Indonesian]

Puupponen-Pimiä R, Nohynek L, Meier C, Kähkönen M, Heinonen M, Hopia A, Oksman-Caldentey K-M. 2001. Antimicrobial properties of phenolic compounds from berries. J Appl Microbiol 90 (4): 494-507. DOI: 10.1046/j.1365-2672.2001. 01271.x

Satrio RD, Fendiyanto MH, Suharsono, Supena EDJ, Miftahudin. 2019 Identification of drought-responsive regulatory genes by hierarchical selection of expressed sequence tags and their expression under drought stress in rice. Intl J Agric Biol 22 (6): 1524-1532.

Scalbert A. 1991. Antimicrobial properties of tannins. Phytochemistry 30 (12): 3875-3883. DOI: 10.1016/0031-9422(91)83426-L.

Schunack W, Mayer K, Haake M. 1990. Medical Compound. Universitas Gajah Mada Press, Yogyakarta. [Indonesian]
Sumardi. 1998. Detection and characterization of antibacterial compounds from microbial extracts and isolates in earthworms Allolobophora rosea. Institut Pertanian Bogor Press, Bogor. [Indonesian]

Soerjani M, Kostermans AJGH, Tjitrosoepomo G. 1987. Weeds of Rice in Indonesia. Balai Pustaka, Jakarta.

Steenis CGGJ. 2006. Mountain Flora of Java. 2nd ed. E.J. Brill. Leiden.

Tabasso S. 2006. Fungal Metabolites: Isolation, Structural Characterization, Bioactivity and Synthesis. Universita' Degli Studi Di Torino, Torino.

Tjitrosoedirdjo SS. 2005. Inventory of the invasive alien plant species in Indonesia. Biotropia 25: 60-73.

Valgas C, DeSouza SM, Smânia EFA. 2007. Screening methods to determine antibacterial activity of natural products. Braz J Microbiol 38: 369-380. DOI: 10.1590/S1517-83822007000200034.

Winarno FG. 1997. Kimia Pangan dan Gizi. Gramedia, Jakarta. [Indonesian]

Xu Y, Burton S, Kim C, Sismour E. 2015. Phenolic compounds, antioxidant, and antibacterial properties of pomace extracts from four Virginia-grown grape varieties. Food Sci Nutr 4 (1): 125-133. DOI: $10.1002 / \mathrm{fsn} 3.264$ 